\title{
Procedural Due Process in Tax Collection: An Opportunity for a Prompt Postdeprivation Hearing
}

Recent well-known Supreme Court decisions ${ }^{1}$ have established the basic elements of procedural due process for governmental actions $^{2}$ that deprive an individual of his property. This comment examines the element of an opportunity to be heard in the context of state and federal tax collection. ${ }^{3}$

Due process ordinarily requires that when an individual may be deprived of his property by a governmental action he must be afforded an opportunity to be heard. In different situations, however, the hearing may be afforded at different times. When the governmental action serves a particularly urgent need, the Court has held that the availability of a hearing through a subsequent suit for redress may be sufficient. But when the governmental action does not serve a particularly urgent need, the Court has in recent cases held that an individual deprived of his property is entitled to more than the availability of a subsequent suit for redress. ${ }^{4}$ Instead, due process requires an opportunity for either a predeprivation hearing or a prompt postdeprivation hearing to test the probable validity of the deprivation in order to minimize the possibility of harm due to a wrongful taking. The primary difference between a predeprivation or a prompt postdeprivation hearing and a subsequent suit for redress is a temporal one. These earlier "hearings" may be held before

' Mathews v. Eldridge, 424 U.S. 319 (1976); North Ga. Finishing, Inc. v. Di-Chem, Inc., 419 U.S. 601 (1975); Mitchell v. W.T. Grant Co. 416 U.S. 600 (1974); Fuentes v. Shevin, 407 U.S. 67 (1972); Goldberg v. Kelly, 397 U.S. 254 (1970); Sniadach v. Family Fin. Corp., 395 U.S. 337 (1969).

2 "Governmental action" includes private action under color of law, such as the use of judicial proceedings and summary remedies provided by statute. In testing governmental action for procedural due process violations, the statute under which action was taken is generally the focal point of the inquiry. When balancing the competing interests the Court has generally given direct governmental needs greater weight than private needs. See CaleroToledo v. Pearson Yacht Leasing Co., 416 U.S. 663, 678-79 (1974); Fuentes v. Shevin, 407 U.S. $67,90-92$ (1972). Nevertheless, all governmental actions are subject to procedural due process requirements. Compare Goldberg v. Kelly, 397 U.S. 254 (1970) (direct governmental action), with Sniadach v. Family Fin. Corp., 395 U.S. 337 (1969) (private use of statutory remedies).

3 Taxation, whether state or federal, generally involves three steps. The first step is levy of the tax, which is the legislative enactment of the legal basis for taxation. The second step is assessment of the tax, either by a governmental assessor or through self-assessment. The assessment establishes the sum due by each taxpayer. Finally, there is collection of the tax, either through voluntary remittance of the amount due or governmental seizure of the taxpayer's assets.

'See, e.g., Fuentes v. Shevin, 407 U.S. 67, 90-93 (1972); Goldberg v. Kelly, 397 U.S. 254, 264-66 (1970). 
an administrative body rather than a court and need only determine whether probable cause for the seizure existed, but they must be held before or promptly after the seizure. This temporal difference is crucial because the earlier hearings can prevent the harm that would occur before a subsequent suit for redress could be brought. ${ }^{5}$

The tax collection procedures of many states do not afford either predeprivation or prompt postdeprivation "probable cause" hearings. ${ }^{6}$ These states have relied on dicta in early Supreme Court cases $^{7}$ to justify tax collection measures that provide an opportunity for a hearing only through a subsequent suit for redress. However, the Supreme Court's recent decision in Commissioner v. Shapiro invites scrutiny of these tax collection procedures. In dictum in Shapiro the Court said that the taxpayer in a federal jeopardy tax collection (an immediate seizure of assets when the government believes the collection of the tax would be "jeopardized" by delay)" should be afforded an opportunity for a probable cause determination in a prompt postdeprivation hearing if he can prove that he will

- The recent cases conflict as to whether a predeprivation or prompt postdeprivation hearing is required. See text at note 46 infra.

- The states often have both ordinary and jeopardy tax collection procedures. For a discussion of the difference between the two types of procedures, see note 74 infra.

State tax collection statues that do not provide either a predeprivaton or a prompt postdeprivation hearing in their ordinary tax collection procedures include; ALASKA STAT. $\$ \S$ 43.10.030, 43.15.010 (1962); CAL. REv. \& TAX CoDE $\$ \$ 6451,6486,6561,6796,6902$ (1970); Conn. Gen. Stat. Ann. $\$ \S 12-35,12-155$ (West 1960); Dez. Code tit. $30 \S \S 1505,1509,5120$, 5417 (1974); Fla. Stat. ANn. $\$ 212.15$ (West 1976); Ga. Code ANN. $\S \S 92-8432,-8443,-8446$ (1974); HaW. REv. Stat. §§ 231-25, 238-8 (1975); IDAHO CoDE $\S \S 63-1214,-1302,-1303$ (1976); IND. Code ANN., §§ 6-1.1-15-10, 6-1.1-23-2 (Burns 1975); Ky. Rev. Stat. § 133.120(5) (1974); Me. Rev. Stat. tit. 36, $\S 381,755,801$ (1971); Miss. Code ANn. $§ 27-35-121$ (1972); Neb. Rev. Stat. §§ 77-1606, -1610, -1502, -1718, -1735 (1971); N.J. STAT. ANn. § 54:29A-57 (West 1941); N.Y. Real Prop. Tax LaW $\S \S 702,704,926$ (McKinney 1958); R.I. GeN. Laws $\S \S 44-5-$ 27, -28 (1970); S.C. CODE § 12-47-210 (1976); UtAh CODE ANN. \$§59-10-4, -5 (1953); Wash. Rev. Code ANN. $\$ \$ 83.48 .010,84.56 .070$ (1970).

State tax collection statutes that do not provide either a predeprivation or prompt postdeprivation hearing in their jeopardy tax collection procedures include: ALA. CODE, tit. 51, $\S$ 217 (1958); Ark. Stat. Ann. § 84-914 (1947); Conn. Gen. Stat. Ann. § 12-36 (West 1960); Fla. Stat. AnN. \$197.092 (West 1976); Ga. Code AnN. \$ 92-8441 (1974); Haw. Rev. Stat. \$ 231-24 (1975); IND. CodE ANN. § 6-2-1-15 (Burns 1975); IowA CODE ANN. $\$ 445.6$ (West 1949); Ky. Rev. Stat. $\$ 134.190$ (1971); ME. Rev. Stat. tit. 36, $§ 1956$ (1964); Md. AnN. Code, art. 81, § 346 (1957); Miss. Code ANn. § 27-35-161 (1972); N.H. Rev. STAT. ANN. § 76:10a (1955); N.M. Stat. ANn. \$ 72-13-72 (1965); N.D. Cent. Code \$\$ 57-22-21.2, -16 (1959); Ohio Rev. Code Ann. \$ 5719.04 (Page 1954); OkLA. Stat. AnN. tit. 68, $\$ 224$ (West 1965); S.D. Compiled Laws Ann. $\$ 10-20-4$ (1967); Tex. Tax-Gen. AnN. art. 7268 (Vernon 1959); Utah Code AnN. § 59-10-22, -23 (1953); W. VA. CODE § 11-15-24a (1965).

7 Bull v. United States, 295 U.S. 247 (1935); Nickey v. Mississippi, 292 U.S. 393 (1934); Phillips v. Commissioner, 283 U.S. 589 (1931). See also Fuentes v. Shevin, 407 U.S. 67, 92 (1972); F. Cooper, State Administrative Law 153-56 (1965).

s 424 U.S. 614 (1976).

- See note 74 infra. 
be irreparably damaged by the seizure. The Shapiro dictum was inspired by recent due process cases emphasizing the availability of a prompt postdeprivation hearing as a way to accommodate the interests of a party seizing property under governmental authority and the party from whom it is taken. The procedure approved in the Shapiro dictum is more restrictive than that required in the cases on which the Court relied, but this difference does not seem justified by the interest balancing approach that the Court purported to adopt. A more careful balancing of the interests indicates that due process requires even more protection than that approved in Shapiro and that significant reforms will be necessary to bring tax collection procedures in many states into compliance with the dictates of due process.

\section{Procedural Due Process and the Deprivation of Property}

Procedural due process specifies what characteristics a proceeding must have when the government, or a private party acting under color of law, seeks to deprive an individual of his life, liberty, or property. ${ }^{10} \mathrm{It}$ is a flexible concept that depends on the identification and comparison of competing interests. ${ }^{11}$ The proceeding must on the one hand protect the individual against the harm of a wrongful deprivation and on the other protect the need for summary action. ${ }^{12}$ The proceeding should provide the individual more protection when his risk of harm is great and the need for summary action small, less protection when his risk of harm is small and the need for summary action great. Although the exact characteristics of a proceeding may vary with each type of governmental action, ${ }^{13}$ the basic elements of

${ }^{10}$ Goldberg v. Kelly, 397 U.S. 254 (1970). "Due process of law" has the same meaning in both the fifth and fourteenth amendments, Hurtado v. California, 110 U.S. 516, 535 (1884), so the procedural due process requirements established by the Supreme Court should apply equally to state and federal governmental actions. What due process requires is often said to be simply "decency and fairness." Breithaupt v. Abram, 352 U.S. 432, 436 (1957).

"Hannah v. Larche, 363 U.S. 420, 442 (1960).

12 In Mathews v. Eldridge, 424 U.S. 319 (1976), the Court said that it had to weigh first, the private interest that will be affected by the official action; second, the risk of an erroneous deprivation of such interest through the procedures used, and the probable value, if any, of additional or substitute procedural safeguards; and finally, the Government's interest, including the function involved and the fiscal and administrative burdens that the additional or substitute procedural requirement would entail.

Id. at 335 . The Court emphasized however, that procedural due process is not a technical concept; rather, the interests involved in each situation must be weighed. Id. at 334 .

${ }_{13}$ See generally Verkuil, A Study of Informal Adjudication Prodecures, 43 U. CHI. L. REv. 739 (1976). 
procedural due process are notice ${ }^{14}$ and an opportunity to be heard ${ }^{15}$ by a fair and impartial tribunal. ${ }^{16}$

When the government has confronted particularly urgent needs, such as a wartime emergency ${ }^{17}$ or a contagion that has threatened the public, ${ }^{18}$ the Supreme Court has allowed it to seize property without affording the property owner a predeprivation or prompt postdeprivation hearing. ${ }^{18}$ In these cases the Court has viewed the need for summary action as so great that the individual need be afforded only a subsequent suit for redress. ${ }^{20}$

Even when the governmental action has not served an urgent need, the Court in early cases said that the availability of a subsequent suit for redress adequately protected the individual against the harm of a wrongful deprivation of property. ${ }^{21}$ The assumption underlying these early cases was that property rights were entitled to less constitutional protection than personal rights. ${ }^{22}$ In recent

"A recurrent question is the sufficiency of notice. Notice must be reasonable and adequate for its purpose, with due regard being given to the type of proceeding and the rights affected by it. Missouri ex rel. Hurwitz v. North, 271 U.S. 40, 42 (1926). See, e.g., Mullane v. Central Hanover Bank \& Trust Co., 339 U.S. 306 (1950) (notice by publication is not sufficient merely because a proceeding is labeled "in rem"). See also Note, The Constitutionality of Notice by Publication in Tax Sale Proceedings, 84 YALE L.J. 1505 (1975).

15 See generally Friendly, "Some Kind of Hearing," 123 U. PA. L. Rev. 1267 (1975). Judge Friendly has concluded that the Supreme Court generally requires a trial-type hearing, including notice and the opportunity to confront and cross-examine witnesses, possibly with the right to counsel. Id. The hearing provided must be practicable and reasonable under all the circumstances. Dohany v. Rogers, 281 U.S. 362, 369 (1930). Reasonable conditions, such as the posting of bond or security, may also be required. Ownbey v. Morgan, 256 U.S. 94 (1921).

14 The tribunal need not be judicial. Goldberg v. Kelly, 397 U.S. 254, 271 (1970). See Smith v. Department of Registration \& Educ., 412 Ill. 332, 106 N.E.2d 722 (1952). See also Friendly, supra note 15, at 1279. The lack of judicial review of the decision of a fair and impartial administrative tribunal is not a denial of procedural due process. Michigan Cent. Ry. v. Powers, 201 U.S. 245 (1906).

"Stoehr v. Wallace, 255 U.S. 239 (1921).

1" North Am. Cold Storage Co. v. City of Chicago, 211 U.S. 306 (1908).

1 Calero-Toledo v. Pearson Yacht Leasing Co., 416 U.S. 663, 679 (1974) (seizure of yacht carrying contraband); Coffin Bros. \& Co. v. Bennett, 277 U.S. 29 (1928) (bank failure); Ewing v. Mytinger \& Casselberry, Inc., 339 U.S. 594 (1950) (misbranded drugs).

${ }_{20}$ It could be argued that a prompt postdeprivation hearing should be required even in emergency situations, since the original seizure satisfies the government's need for immediacy and the prompt postdeprivation hearing would minimize the possibility of harm to the individual. The Court's dictum in Commissioner v. Shapiro, 424 U.S. 614 (1976), supports this conclusion. See note 82 infra. However, the Court has not had to address this issue directly in recent years, and the cases still support the proposition that in emergency situations the opportunity for a suit for subsequent redress is sufficient. See Fuentes v. Shevin, 407 U.S. 67, 90-92 (1972).

21 Phillips v. Commissioner, 283 U.S. 589 (1931) (citing Springer v. United States, 102 U.S. $586(1880))$.

${ }^{22}$ Compare United States v. Woo Jan, 245 U.S. 552 (1918), with McKay v. McInnes, 279 U.S. 820 (1929), and Ownbey v. Morgan, 256 U.S. 94 (1921). 
cases, however, the Court has repudiated this assumption ${ }^{23}$ and has held that, at least in the absence of an urgent governmental need, the interests of the individual require more protection than the availability of a subsequent suit for redress. In 1969 in Sniadach $v$. Family Finance Corp. ${ }^{24}$ the Court held unconstitutional a statute that allowed the garnishment of wages. The Court said that a wage garnishment statute that did not provide a hearing before the debtor was deprived of the unrestricted use of his property violated due process..$^{25}$ Similarly, the next year in Goldberg $v$. Kelly ${ }^{26}$ the Court held unconstitutional the termination of public assistance payments without a pretermination evidentiary hearing at which an initial determination of the validity of the termination could be made.

The opinions in both Sniadach and Goldberg stressed the possibility of irreparable harm, although neither opinion used the familiar language of equity. The Court in Sniadach said that wages were a "specialized type of property" ment "may as a practical matter drive a wage-earning family to the wall." 28 In Goldberg the Court said that "termination of aid pending resolution of a controversy over eligibility may deprive an eligible recipient of the very means by which to live while he waits." ${ }^{29}$ In each case, the harm imposed could not be remedied by the availability of a subsequent suit for redress or, to use the language of equity, there was an inadequate remedy at law. It is important to note that, unlike in equity practice, the Court did not actually require a showing of irreparable harm in the particular case. In fact,

${ }^{23}$ The right to enjoy property without unlawful deprivation, no less than the right to speak or the right to travel, is in truth a "personal" right, whether the "property" in question be a welfare check, a home, or a savings account. In fact, a fundamental interdependence exists between the personal right to liberty and the personal right in property. Neither could have meaning without the other. That rights in property are basic civil rights has long been recognized.

Lynch v. Household Finance Corp., 405 U.S. 538, 552 (1972) (rejecting distinction between property rights and personal liberties as applied to jurisdiction under 28 U.S.C. $\S 1343(3)$ (1970)).

24 395 U.S. 337 (1969).

${ }^{25}$ In his concurring opinion, Justice Harlan stated that "due process is afforded only by the kinds of 'notice' and 'hearing' which are aimed at establishing the validity, or at least the probable validity, of the underlying claim against the alleged debtor before he can be deprived of his property or its unrestricted use." 395 U.S. at 343. The Court adopted this view of Sniadach in Fuentes v. Shevin, 407 U.S. 67, 97 (1973).

\footnotetext{
${ }^{25} 397$ U.S. 254 (1970).

27395 U.S. at 340.

2x Id. at $341-42$.

29397 U.S. at 264.
} 
in Sniadach only $\$ 31.59$ of the debtor's wages were withheld, probably imposing a de minimis harm. ${ }^{30}$ Instead, the Court in both cases examined the possibility of harm on a categorical basis.

Both Sniadach and Goldberg involved situations in which an individual often has dire need for the property being taken. In the 1972 case of Fuentes $v$. Shevin, ${ }^{31}$ however, the Court challenged the notion that dire necessity was the basis of the holdings in those cases. ${ }^{32}$ Fuentes involved not the "absolute necessities of life" 33 but consumer goods purchased on conditional sale. The Court held unconstitutional replevin statutes that did not provide for a hearing before the goods were repossessed. In a subsequent case the Court extended similar protection to goods replevied from a commercial entity; ${ }^{34}$ in this commercial situation, the Court reemphasized that the inadequacy of a subsequent suit for redress is not a function of the nature of the property right involved. ${ }^{35}$ Although these cases have continued to speak in terms of the possibility of irreparable harm, they in fact appear to be based simply on the right to use property ${ }^{36}$ - whenever an individual has been deprived of the use of

${ }^{30}$ See 395 U.S. at 346 (Black, J., dissenting).

" 407 U.S. 67 (1972).

32 Id. at 88. The Court said that Sniadach and Goldberg

were in the mainstream of past cases, having little or nothing to do with the absolute "necessities" of life but establishing that due process requires an opportunity for a hearing before a deprivation of property takes effect. In none of those cases did the Court hold that this most basic due process requirement is limited to the protection of only a few types of property interests. While Sniadach and Goldberg emphasized the special importance of wages and welfare benefits, they did not convert that emphasis into a new and more limited constitutional doctrine.

....

. . . The Fourteenth Amendment speaks of "property" generally. . . . It is not the business of a court adjudicating due process rights to make its own critical evaluation of property interests and protect only the ones that, by its own lights, are "necessary." Id. at 88-90 (citations omitted). See also North Ga. Finishing, Inc., v. Di-Chem, Inc., 419 U.S. 601,608 (1975).

707 U.S. at 88.

* North Ga. Finishing, Inc. v. Di-Chem, Inc., 419 U.S. 601 (1975).

3s Id. at 608 . See note 32 supra.

"Although the Court in Fuentes never used the exact phrase "irreparable harm," it used very similar language. The Court said:

At a later hearing, an individual's possessions can be returned to him if they were unfairly or mistakenly taken in the first place. Damages may even be awarded to him for the wrongful deprivation. But no later hearing can undo the fact that the arbitrary taking that was subject to the right of procedural due process has already occurred.

407 U.S. at 81-82. The Court in Di-Chem specifically referred to the possible irreparable injury:

Respondent also argues that neither Fuentes nor Mitchell is apposite here because each of those cases dealt with the application of due process protections to consumers who are victims of contracts of adhesion and who might be irreparably damaged by 
his property, the Court has found a possibility of irreparable harm..$^{37}$ Nevertheless, the possibility of irreparable harm has not always led to a predeprivation hearing. Although Goldberg specifically required a predeprivation hearing ${ }^{38}$ and broad language in Fuentes suggested that a hearing "must be granted at a time when the deprivation can still be prevented," ${ }^{39}$ other cases have held that a prompt postdeprivation hearing adequately protects against harm. In 1974 in Mitchell v. W.T. Grant Co., ${ }^{40}$ the Court approved sequestration procedures that provided an opportunity for a prompt postdeprivation hearing. A predeprivation hearing would have inadequately protected the creditor against the risk of concealment or transfer of the property. ${ }^{41}$ The next year in North Georgia Finishing Inc. $v$. Di-Chem, Inc. ${ }^{42}$ the Court required only that a garnishment statute provide "an early hearing at which the creditor would be required to demonstrate at least probable cause for the garnishment." "33 Similarly, in 1976 in Mathews $v$. Eldridge ${ }^{44}$ the Court upheld procedures of the Social Security Administration for the termination of disability benefits that provided an opportunity for a prompt posttermination hearing..$^{45}$

Taken together, these recent cases support several generaliza-

temporary deprivation of household necessities, whereas this case deals with its application in the commercial setting to a case involving parties of equal bargaining power. ... It may be that consumers deprived of household appliances will more likely suffer irreparably than corporations deprived of bank accounts, but the probability of irreparable injury in the latter case is sufficiently great so that some procedures are necessary to guard against the risk of initial error. We are no more inclined now than we have been in the past to distinguish among different kinds of property in applying the Due Process Clause. Fuentes v. Shevin, 407 U.S. at 89-90.

419 U.S. at 608 . The Court repeated the language of "irreparable injury" in Shapiro v. Commissioner, 424 U.S. 614 (1976):

This Court has recently and repeatedly held that, at least where irreparable injury may result from a deprivation of property pending final adjudication of the rights of the parties, the Due Process Clause requires that the party whose property is taken be given an opportunity for some kind of predeprivation or prompt post-deprivation hearing at which some showing of the probable validity of the deprivation must be made.

Id. at 629 .

37 See Clark \& Landers, Sniadach, Fuentes and Beyond: The Creditor Meets the Constitution, 59 VA. L. REv. 355 (1973); Newton, Fuentes "Repossessed" Reconsidered, 28 BAYLOR L. REv. 497 (1976).

3* Goldberg v. Kelly, 397 U.S. 254, 267 (1970).

39 407 U.S. 67, 97 (1972). See Sniadach v. Family Fin. Corp., 395 U.S. 337, 343 (1969)

(Harlan, J., concurring).

10416 U.S. 600 (1974).

"Id. at 608 .

$s^{2} 419$ U.S. 601 (1975).

s3 Id. at 607.

4424 U.S. 319 (1976).

15 Id. at $335-39$. 
tions. Each case has required that some kind of hearing prior to a subsequent suit for redress be available. A subsequent suit for redress would, of course, provide a plenary hearing and would be initiated by the individual deprived of his property. The earlier hearing required by due process need not be plenary, be in a judicial forum, or have all the elements of a trial-type hearing; but it must afford the individual an opportunity to be heard at the time of the taking or promptly thereafter, and must be designed to test the probable validity of the deprivation. The reason given for providing such a hearing has been the possibility of harm, but the cases have looked to the possibility of harm on a categorical basis rather than requiring a showing of irreparable harm in each case. For example, it has been sufficient to trigger a probable cause hearing if the garnishment of wages or the replevying of consumer goods will, in some cases, impose an irreparable harm.

The cases disagree, however, as to the exact time at which such a hearing must be made available, and the Court has not adequately addressed this conflict. Several cases have stated that a predeprivation hearing is required, while other cases have flatly held that a predeprivation hearing is not necessary. For example, Goldberg $v$. Kelly held that a pretermination hearing was required when welfare payments were stopped, but Mathews $v$. Eldridge upheld procedures for the termination of Social Security disability benefits that afford the individual only a prompt postdeprivation hearing. This apparent conflict is not easily explained. Certainly the Court has considered many factors in its due process analysis, and perhaps the cases could be reconciled by looking to factors such as the nature of the property interest or the likely indigency of the deprived party. However, the Court has in other cases disclaimed the importance of these factors. ${ }^{46}$ Further, the cases cannot be reconciled by looking to whether the property is being seized by the government or a private party ${ }^{47}$ Even if the cases could be reconciled on their facts, the Court's discussions of whether a predeprivation or prompt postdeprivation hearing is required in the various cases would still be

* See note 32 supra. Another possible approach would be to apply the factors that the Court has disclaimed in determining whether procedural due process generally applies to determine the time when a hearing must be available. The nature of the property interest involved and the type of deprivation (for example, replevin or tax seizure) could determine whether or not a preseizure hearing must be available, although for all property interests some kind of hearing must be afforded prior to a subsequent suit for redress. The apparent conflict between Mathews $v$. Eldridge and Goldberg $v$. Kelly could be explained on these grounds.

${ }_{17}$ See cases discussed in note 36 supra. See also Mashaw, The Supreme Court's Due Process Calculus for Administrative Adjudication in Mathews v. Eldridge: Three Factors in Search of a Theory of Value, 44 U. CHI. L. REv. 28 (1976). 
inconsistent. ${ }^{48}$ The Court has vacillated in requiring a predeprivation or prompt postdeprivation hearing and has simply failed to acknowledge or explain its inconsistencies.

Nevertheless, this line of cases may perhaps be understood as an evolution. The early cases, such as Sniadach and Fuentes, broadly attacked the prior view that due process required only the availability of a subsequent suit for redress. In sweeping language the Court said that a predeprivation hearing was required to accord due process, although the holding of most of these cases was narrower since the Court simply invalidated statutes that provided only a subsequent suit for redress. In contrast, since Mitchell the Court has modified the sweeping position of the earlier cases and has held that a prompt postdeprivation hearing is sufficient. ${ }^{49}$ Such a hearing still provides an opportunity to correct wrongful deprivations before much harm is suffered; furthermore, a prompt postdeprivation hearing respects the need for summary action since the necessary seizure is allowed before the hearing.

The Supreme Court's apparent shift from requiring an opportunity for a predeprivation hearing to requiring only an opportunity for a prompt postdeprivation probable cause hearing as the favored solution to procedural due process interest balancing may be criticized as a symptom of a general retreat from the protection of individual rights. However, the flexibility offered by this more limited procedural alternative may expand the protection of individuals' rights in some instances. This possibility for expanded protection is most pronounced in those situations-such as tax collection and wartime emergencies-in which the urgency of the governmental interest has in the past prevented the courts from making predeprivation remedies available as a due process right. The older cases, even including Fuentes $v$. Shevin, which reaffirmed the constitutional adequacy of a subsequent suit for redress where urgent governmental needs were involved, ${ }^{50}$ suffer from a limited awareness of the procedural alternatives available to accommodate the interests of the state with those of the individuals whose liberty or property is affected. Finding a predeprivation hearing unacceptable, these cases embraced the adequacy of a subsequent suit for redress with(1973).

43 Compare Goldberg v. Kelly, 397 U.S. 254 (1970), with Fuentes v. Shevin, 407 U.S. 67

"Such an interpretation was strongly urged by the Court in North Ga. Finishing, Inc., v. Di-Chem, Inc., 419 U.S. 601 (1975), when it attempted to reconcile Mitchell v. W.T. Grant Co., 416 U.S. 600 (1974), with the earlier cases.

s0 407 U.S. 67, 91-92 (1972). 
out considering the compromise position offered by a prompt postdeprivation hearing.

The Supreme Court addressed the implications of this new procedural possibility in the context of one of the traditional "urgent governmental need" situations for the first time in a suit involving the seizure of property to collect federal taxes.51 Although the Court's statements are mere dicta and although the peculiar circumstances of the suit may have led the Court to affirm procedures that are less protective than a more careful balancing of the interests would dictate, the case at least promises that the new flexibility offered by prompt postdeprivation hearings may lead to increased due process protection in cases involving "urgent governmental needs."

\section{Procedural Due Process in Tax Collection}

\section{A. The Traditional Approval of Tax Collection Procedures}

The due process cases would seem to require that when the government seizes property to satisfy a tax obligation, the taxpayer must be afforded an opportunity for at least a prompt postdeprivation hearing. The relationship of the taxpayer to the government is analogous to the relationship of a debtor to his creditor, and the taxpayer faces a similar risk of irreparable harm due to a wrongful deprivation of his property. But courts have approved tax collection procedures that allow only an opportunity for a subsequent suit for redress and have relied on dicta from several Supreme Court cases to reach this result.

An example is the Ninth Circuit's recent decision in Bomher $v$. Reagan. ${ }^{52} \mathrm{~A}$ taxpayer argued that the summary tax collection procedures used by California's Franchise Tax Board offended due process by allowing seizure of the taxpayer's property without a prior hearing. The court quickly dismissed the argument and upheld the statute, which provided a hearing only through a suit for refund of the tax. The court said:

Summary tax collection procedures, which provide for subsequent judicial review, have been sustained against constitutional challenge since the case of Phillips $v$. Commissioner. The Court there held that such procedures neither deprived a taxpayer of due process nor amounted to an unconstitutional 
delegation of judicial authority to the executive branch of government. The exception in tax matters to prior notice and hearing was more recently reaffirmed in Fuentes $v$. Shevin. The fact that a taxpayer disputes the tax debt, as appellant asserts he does here, does not alter the rule of Phillips. ${ }^{53}$

In approving similar tax collection procedures, other courts ${ }^{54}$ have regularly turned for support to broad language in Phillips $v$. Commissioner ${ }^{55}$ and another case, Nickey v. Mississippi. ${ }^{56}$ Both Phillips and Nickey, however, merit reexamination in light of the recent due process cases because the broad propositions for which they have been cited conflict with the analysis of the more recent cases. ${ }^{57}$ In fact, the actual holdings in both Phillips and Nickey were narrower and can readily be reconciled with the more recent cases.

To understand Phillips and Nickey better, it will be helpful to recount some of the cases leading up to Phillips. In the 1880 case of Springer $v$. United States ${ }^{58}$ the Court upheld the distraint of personal property for the collection of taxes. The Court said that distraint was available at common law and that taxpayers could not delay the collection of revenue through litigation. ${ }^{59} \mathrm{~A}$ factor in the

53 Id. at 1202 (citations omitted).

s See, e.g., Creque v. Shulterbrandt, 121 F. Supp. 448 (D.V.I. 1954); Gainesville-Hall County Economic Opportunity Organization, Inc. v. Blackmon, 233 Ga. 507, 212 S.E.2d 341 (1975); Frye v. Haas, 182 Neb. 73, 152 N.W.2d 121 (1967) (dictum).

283 U.S. 589 (1931).

s6 292 U.S. 393 (1934).

57 See Mitchell v. W.T. Grant Co., 416 U.S. 600 (1974); Fuentes v. Shevin, 407 U.S. 67 (1972); North Ga. Finishing, Inc. v. Di-Chem, Inc., 419 U.S. 601, 609 (1975) (Powell, J., concurring).

s8 102 U.S. $586(1880)$.

${ }^{59}$ Id. at 594. See Bull v. United States, 295 U.S. 247, 259 (1935). The Court in Bull carefully described the changes made in normal judicial processes to accommodate taxation.

A tax is an exaction by the sovereign, and necessarily the sovereign has an enforcible claim against every one within the taxable class for the amount lawfully due from him. The statute prescribes the rule of taxation. Some machinery must be provided for applying the rule to the facts in each taxpayer's case, in order to ascertain the amount due. The chosen instrumentality for the purpose is an administrative agency whose action is called an assessment. The assessment may be a valuation of property subject to taxation which valuation is to be multiplied by the statutory rate to ascertain the amount of tax. Or it may include the calculation and fix the amount of tax payable, and assessments of federal estate and income taxes are of this type. Once the tax is assessed the taxpayer will owe the sovereign the amount when the date fixed by law for payment arrives. Default in meeting the obligation calls for some procedure whereby payment can be enforced. The statute might remit the Government to an action at law wherein the taxpayer could offer such defense as he had. A judgment against him might be collected by the levy of an execution. But taxes are the life-blood of government, and their prompt and certain availability an imperious need. Time out of mind, therefore, the sovereign has resorted to more drastic means of collection. The assessment is given the force of a 
Court's decision was its belief that property rights were entitled to less constitutional protection than personal liberties. ${ }^{60}$ Four years later in Hagar v. Reclamation District No. $108^{81}$ the Court held that the assessment of a tax without prior notice and hearing did not offend due process. ${ }^{62}$ However, the Court said in a dictum that prior notice and hearing was required in some cases before the enforcement of a tax. ${ }^{63}$ This dictum contradicted the holding in Springer.

judgment, and if the amount assessed is not paid when due, administrative officials may seize the debtor's property to satisfy the debt.

In recognition of the fact that erroneous determinations and assessments will inevitably occur, the statutes, in a spirit of fairness, invariably afford the taxpayer an opportunity at some stage to have mistakes rectified. Often an administrative hearing is afforded before the assessment becomes final; or administrative machinery is provided whereby an erroneous collection may be refunded; in some instances both administrative relief and redress by an action against the sovereign in one of its courts are permitted methods of restitution of excessive or illegal exaction. Thus the usual procedure for the recovery of debts is reversed in the field of taxation. Payment precedes defense, and the burden of proof, normally on the claimant, is shifted to the taxpayer. The assessment supersedes the pleading, proof and judgment necessary in an action at law, and has the force of such a judgment. The ordinary defendant stands in judgment only after a hearing. The taxpayer often is afforded his hearing after judgment and after payment, and his only redress for unjust administrative action is the right to claim restitution. But these reversals of the normal process of collecting a claim cannot obscure the fact that after all what is being accomplished is the recovery of a just debt owed the sovereign.

295 U.S. at $259-60$.

102 U.S. at 594. The Court in Phillips v. Commissioner, 283 U.S. 589, 595 (1931), so read Springer's discussion of the government's power to distrain property.

11 111 U.S. 701 (1884).

:2 Id. at 708. Since an assessment shifts the burden of proof to the taxpayer, it is arguably a deprivation of property. Armstrong v. Manzo, 380 U.S. 545 (1965), lends some support to this argument. In Armstrong lack of notice of hearings led to a default judgment against petitioners; the petitioners were able to challenge this judgment but bore the burden of proof. The Court ruled that since the placement of the burden of proof can often determine the outcome, the lack of notice was a deprivation of procedural due process. Similar reasoning could be applied to tax assessments. Since the assessment places the burden of proof on the taxpayer, lack of notice prior to the assessment could be viewed as deprivation of property. However, courts have consistently concluded that notice and hearing prior to assessment are not required because the government's need for an administratively acceptable means to assess large numbers of taxpayers outweighs the taxpayer's interest, especially since no property is physically taken. See, e.g., Hagar v. Reclamation Dist. No. 108, 111 U.S. 701 (1884); McGregor v. Hogan, 263 U.S. 234 (1923). Armstrong is distinguishable since only one person was involved and thus personal notice was administratively feasible.

a The Court said:

Undoubtedly where life and liberty are involved, due process requires that there be a regular course of judicial proceedings, which imply that the party to be affected shall have notice and an opportunity to be heard; so, also, where title or possession of property is involved. But where the taking of property is in the enforcement of a tax, the proceeding is necessarily less formal, and whether notice to him is at all necessary may depend on the character of the tax, and the manner in which its amount is determinable. The necessity of revenue for the support of the government does not admit of the delay 
In 1905 the Court held in Hodge v. Muscatine County ${ }^{64}$ that the taxpayer was entitled to notice but not a hearing before a tax lien attached to his property. The Court also said that due process was not offended so long as the taxpayer was "given an opportunity to test the validity of a tax at any time before it is made final." ${ }^{65}$ Since the statute in Hodge in fact afforded the taxpayer a hearing prior to the enforcement of the lien, the Court did not have to reach the question whether collection of the tax by enforcement of the lien without a hearing would be permissible.

Some state courts have interpreted Phillips $v$. Commissioner ${ }^{66}$ as reaching this further question. In Phillips a shareholder had been assessed the tax deficiency owed by a dissolved corporation. The shareholder argued that due process required a judicial hearing before the tax was collected. But the Court upheld the statute and to support its conclusion used broad language that has been read to permit summary collection of taxes without providing more than an opportunity for a subsequent suit for redress. The Court said, "Where, as here, adequate opportunity is afforded for a later judicial determination of the legal rights, summary proceedings to secure prompt performance of pecuniary obligations to the government have been consistently sustained." ${ }^{67}$ The Court also said that "where only property rights are involved, mere postponement of the judicial enquiry is not a denial of due process, if the opportunity given for the ultimate judicial determination of the liability is adequate."68 However, a close examination of Phillips shows that its holding was a narrow one. The Court pointed to two alternate remedies available to the taxpayer. First, the taxpayer could obtain a judicial hearing after the tax had been collected or paid. Second, the taxpayer could obtain an administrative hearing before the tax was collected or paid. The holding of Phillips thus was simply that an opportunity for a judicial hearing was not required before the tax

attendant upon proceedings in a court of justice, and they are not required for the enforcement of taxes or assessments.

111 U.S. at 708 (emphasis added).

of 196 U.S. 276 (1905).

${ }^{65} \mathrm{Id}$. at 281.

${ }^{66} 283$ U.S. 589 (1931).

67 Id. at 595 .

${ }^{68}$ Id. at 596-97. This statement was based on Springer v. United States, 102 U.S. 586 (1880), to the extent it says there is no due process violation because "only property rights are involved." Both Phillips and Springer assumed that property rights are entitled to less constitutional protection than personal liberties. To the extent Phillips relied on this distinction, the case has little vitality beçause the distinction is very tenuous in light of the more recent due process cases. See text and notes at notes 28-46, supra. 
was collected; Phillips did not hold that the tax could be collected without any opportunity for a hearing.

Similarly, courts have interpreted language in Nickey $v$. Mississippi ${ }^{69}$ to justify tax collection procedures that afford the taxpayer an opportunity for only a subsequent suit for redress. In fact, Nickey simply reaffirmed the holding in Hagar that due process did not require notice and hearing before the assessment of a tax. The Court noted that the state's suit to collect the tax provided the taxpayer an opportunity to challenge the assessment before the liability to pay the tax became final. As in Phillips, the procedures at issue in Nickey actually provided an opportunity for a predeprivation hearing.

Examination of the Phillips and Nickey cases thus shows that neither established a special exception to the requirements of procedural due process for tax collection. Instead, each case is entirely consistent with the proposition that an opportunity for either a predeprivation or prompt postdeprivation hearing is required when a taxpayer's property is taken because in each case the taxpayer was afforded an opportunity for such a hearing. Nonetheless, many states have enacted tax collection statutes that afford the taxpayer neither a predeprivation nor a prompt postdeprivation hearing, and courts have relied on broad readings of Phillips and Nickey to uphold such tax collection procedures. ${ }^{70}$ The broad reading of Phillips was given credence by the Court when it cited Phillips in a recent due process case ${ }^{71}$ to support its categorization of the collection of tax revenue with the particularly urgent governmental needs that have justified the summary seizure of property. ${ }^{72}$

4 292 U.S. 393 (1934).

70 Bomher v. Reagan, 522 F.2d 1201 (9th Cir. 1975); Creque v. Shulterbrandt, 121 F. Supp. 448 (D.V.I. 1954); Faix, Ltd. v. County of Los Angeles, 54 Cal. App. 3d 992, 127 Cal. Rptr. 182 (1976); Gainesville-Hall County Economic Opportunity Organization, Inc, v. Blackmon, 233 Ga. 507, 212 S.E.2d 341 (1975); Frye v. Haas, 182 Neb. 73, 152 N.W.2d 121 (1967) (dictum).

"Fuentes v. Shevin, 407 U.S. 67, 91-92 (1972).

72 In Great Lakes Dredge \& Dock Co. v. Huffman, 319 U.S. 293 (1943), the Court also used sweeping language in dictum that suggested that a refund suit was an "adequate" remedy in state tax collection. Id. at 301 . However, the issue facing the Court in Huffman was whether the federal courts should issue declaratory judgments concerning the collection of state taxes when, under what is now 28 U.S.C. $\$ 1341$ (1970), the same federal courts would not be able to enjoin the collection of the tax. The Court equated injunctive and declaratory relief, and held that federal courts should not be able to issue declaratory judgments concerning state tax collection. In contrast to their reliance on Phillips and Nickey, state courts have not relied on the dictum in Huffman to support the conclusion that a subsequent suit for redress is sufficient. 


\section{B. A Reappraisal of Tax Collection Procedures}

In a 1976 case construing a section of the Internal Revenue Code, the Supreme Court said in dictum that jeopardy tax collection procedures ought to provide a taxpayer who can show he will be irreparably harmed by the seizure an opportunity for at least a prompt postdeprivation hearing testing the probable validity of the taking. If the Court's analysis is correct, tax collection can no longer be treated as a particularly urgent governmental need for which the availability of a subsequent suit for redress suffices to afford due process.

1. Jeopardy Collection. In Commissioner v. Shapiro ${ }^{73}$ a taxpayer had been ordered extradited to Israel to stand trial on criminal charges. The Commissioner of Internal Revenue had found, pursuant to section 6861 of the Code, that the collection of taxes for prior years would be jeopardized by delay. Ordinarily the Internal Revenue Service does not collect taxes by seizing the taxpayer's assets until the taxpayer has had an opportunity to be heard in the Tax Court. However, if the Commissioner finds that the collection of tax is jeopardized, ${ }^{74}$ the Code provides that upon notice and demand for the tax and a failure of payment the Commissioner may seize the taxpayer's assets to satisfy the tax ${ }^{75}$ In Shapiro the Commissioner had made a jeopardy assessment of taxes and had immediately seized the taxpayer's bank accounts and safe deposit boxes. The taxpayer had sought to enjoin the seizure because he needed the money to post bail in Israel and because he allegedly did not know whether he owed any taxes. ${ }^{76}$

The Court's decision in Shapiro was specifically based on a statutory ground. The Court considered the availability of an injunction in light of the Internal Revenue Code Anti-Injunction Act,

${ }^{73} 424$ U.S. 614 (1976).

${ }^{74}$ Jeopardy assessment and collection apply to those taxes whose collection the taxing authority believes would be jeopardized by the delay involved in using the ordinary collection procedures. Administrative Conference of the United States, Report on Administrative Procedures of the Internal Revenue Service 284 (1974) [hereinafter cited as Admin. Conf. REPORT]. Examples of situations in which jeopardy assessment and collection are employed include (1) the departure of the taxpayer from the jurisdiction; (2) the removal of the taxpayer's assets from the jurisdiction; (3) the concealment or waste of the taxpayer's assets; or (4) the probability the taxpayer will become insolvent. Internal Revenue Manual (CCH) $\S$ 4584.1(1) (1976).

${ }^{75}$ The Internal Revenue Code uses the term "levy" to describe the seizure of assets in the hands of a third party. ADMIN. CoNF. REPORT, supra note 74 at 255. "Levy," in reference to taxation, has two different senses. Not only does it refer to the process of collecting taxes, but more properly it means to lay. or impose a tax. To avoid confusion, this comment will simply refer to the collection process as the seizure of assets.

${ }^{76} 424$ U.S. at $616-20$. 
which states that "no suit for the purpose of restraining the assessment or collection of any tax shall be maintained in any court by any person." 77 In Enochs $v$. Williams Packing \& Navigation Co. ${ }^{78}$ the Court had announced two conditions which, if satisfied, allow a court to grant an injunction against the collection of a tax despite the apparently absolute language of the Anti-Injunction Act. An injunction is available if the taxpayer can establish (1) extraordinary circumstances causing irreparable harm, for which the taxpayer has no adequate remedy at law and (2) that under the view of the law and facts most favorable to the government it cannot establish its claim. In Shapiro the taxpayer had alleged that he needed the assets to post bail in Israel. A subsequent suit for refunc of the tax would have been an inadequate remedy to prevent the irreparable harm of incarceration. He had also alleged that the tax was groundless. The factual basis for the tax was mostly conclusory, and the government had argued that Williams Packing required the taxpayer to prove that the government cannot prevail. The Court held that the government must at least disclose the factual basis for its jeopardy assessment so that the taxpayer could have a fair chance to show that the government could not prevail. The Court added, however, that for an injunction to issue the taxpayer carried the burden of proving both that he would suffer irreparable harm and that the government's claim was totally untenable. Accordingly, the Court remanded the case for factual findings that would determine whether an injunction could issue. ${ }^{79}$

The Court's interpretation of the Internal Revenue Code AntiInjunction Act was sufficient to decide Shapiro-on the basis of this interpretation the case was returned to the trial court to determine whether the taxpayer had met the criteria for an injunction. ${ }^{80}$ However, the Court added, in dictum, that its decision was fortified by the demands of procedural due process. The Court said:

[T]o permit the Government to seize and hold property on the mere good-faith allegation of an unpaid tax would raise serious constitutional problems in cases, such as this one, where it is asserted that seizure of assets pursuant to a jeopardy assess-

" I.R.C. $\$ 7421$ (a). This "Anti-Injunction Act" should not be confused with 28 U.S.C. $\S$ 2283 (1970), which is also popularly known as the "Anti-Injunction Act."

in 370 U.S. 1 (1962).

7 424 U.S. at $620-29$.

so The dissent in Shapiro would have dismissed the suit under the Anti-Injunction Act, arguing that this decision would emasculate that Act. 424 U.S. at 634-35. Accordingly, the dissent did not consider the constitutional issues involved in the case. 
ment is causing irreparable injury. This Court has recently and repeatedly held that, at least where irreparable injury may result from a deprivation of property pending final adjudication of the rights of the parties, the Due Process Clause requires that the party whose property is taken be given an opportunity for some kind of a predeprivation or prompt post-deprivaton hearing at which some showing of the probable validity of the deprivation must be made. Here the Government seized respondent's property and contends that it has absolutely no obligation to prove that the seizure has any basis in fact no matter how severe or irreparable the injury to the taxpayer and no matter how inadequate his eventual remedy in the Tax Court. ${ }^{81}$

In a footnote the Court added its belief that although a predeprivation hearing might not be required because it would fail to protect the government's interest in the collection of revenue, an opportunity for at least a prompt postdeprivation hearing was required..$^{82}$

The Court then discussed the Phillips case, upon which the Commissioner had based his argument that an injunction was improper. ${ }^{83}$ The Commissioner had argued that Phillips required no more than an eventual opportunity for review of the seizure in the Tax Court. The Court disagreed with that reading of Phillips because Phillips did not involve a jeopardy assessment and thus the tax collection procedures in that case did not allow the taxpayer's assets to be taken until he had either exercised or waived his right to a hearing in the Tax Court. ${ }^{84}$

An analysis of the competing interests, similar to that employed in the recent due process cases cited by the Court in Shapiro, indicates that due process requires an opportunity for a prompt hearing after a jeopardy seizure to determine the existence of probable cause for the seizure. A taxpayer confronted with a jeopardy

s1 424 U.S. at $629-30$ (footnotes omitted).

22 The Court stated:

We have often noted that, in resolving a claimed violation of procedural due process, a careful weighing of the respective interests is required; and we have noted that the Government's interest in collecting the revenues is an important one. This interest is clearly sufficient to justify seizure of a taxpayer's assets without a preseizure hearing, Fuentes $v$. Shevin, and to remove any need to subject the Commissioner to the burden of an inquiry into the basis for his assessment absent factual allegations of irreparable injury by the taxpayer. However, it is very doubtful that the need to collect the revenues is a sufficient reason to justify seizure causing irreparable injury without a prompt postseizure inquiry of any kind into the Commissioner's basis for his claim.

Id. at 630 n.12 (citations omitted; emphasis by the Court).

See text at notes 55-68 supra.

st 424 U.S. at $630-32$. 
assessment, like a debtor faced with replevin, has in many instances an interest in avoiding irreparable harm due to the interim deprivation of his property. At the same time, the government has an interest in preventing the taxpayer from concealing or transferring assets that should be used to satisfy his tax obligation. Affording the taxpayer an opportunity to be heard, or even notice of the jeopardy assessment, before the assets were seized would leave the government exposed to the risk of concealment or transfer. Protection of the government's interests thus justifies a jeopardy seizure without prior notice or opportunity to be heard. But once the government has control of the taxpayer's assets, the ultimate collection of taxes is no longer jeopardized. An opportunity for a prompt postdeprivation hearing to determine the existence of probable cause does not impede the government's interest and is needed to protect the taxpayer from the irreparable harm that may result from the wrongful seizure of his property.

In Shapiro the taxpayer attempted to enjoin the seizure of his property. in the jeopardy tax collection. Because of this procedural posture, Shapiro differs from the recent due process cases in two ways. First, in the hearings required by the due process cases the party taking the property has had the burden of establishing the probable validity of the taking. In the hearing approved in Shapiro the Court placed the burden of proof on the taxpayer..$^{85}$

Second, the Court required Shapiro to prove irreparable harm in the facts of his case. Again, since Shapiro was seeking an injunction, requiring him to prove irreparable harm accorded with the usual rules of equity. The Court also said, however, that the injunction remedy provided a standard that was at least as favorable to the taxpayer as that which the Constitution requires.

[T] as favorable to the taxpayer as that required by the Constitution .... Affidavits are sufficient so long as they disclose facts from which it appears that the Government may prevail. The Constitution does not invariably require more, and we would

is A taxpayer challenging the seizure of his property may have to bear the burden of proof even if an injunction is not sought. Acknowledging the government's position that the collection of taxes is imperative, the courts have traditionally held that the assessment of a tax shifts the burden of proof to the taxpayer, see note 59 supra, and this presumption would probably be maintained in hearings weighing the probable validity of a seizure of property for taxes. The taxpayer whose property has been seized would then carry the same burden as the taxpayer who voluntarily paid his taxes and subsequently seeks a refund. See Avco Delta Corp. Canada Ltd. v. United States, 540 F.2d 258, 262 (7th Cir. 1976). 
not hold that it does where collection of the revenues is involved. ${ }^{86}$

This statement implies that the individual deprived of his property by a tax seizure may be required to prove irreparable harm in order to set aside a seizure of his property. In effect this means that even if the taxpayer could show that the Government had no probable cause for the seizure, he can do nothing about the seizure unless he can prove that it has caused him irreparable harm. In contrast, the recent due process cases have held that the mere possibility of irreparable harm is sufficient to require a prompt hearing to determine the existence of probable cause for the seizure. The existence of probable cause is the only issue in these hearings; the existence of actual irreparable harm is not considered. Although the Court in Shapiro apparently sought to justify this difference by appealing to the traditional urgent need to collect revenues, this explanation will not withstand analysis. The government's need for revenue is not imperiled because it has the taxpayer's asset in its possession and will have to return the asset only if it had no probable cause for the seizure in the first place. The government's interest in seizing assets when probable cause is lacking seems clearly outweighed by the individual's interest in being protected from a wrongful deprivation. Balancing the interests involved in jeopardy taxation indicates that rather than requiring the taxpayer to prove irreparable harm, the Court should have consistently employed the due process analysis of its recent cases-the jeopardy taxpayer should be afforded at least a prompt postdeprivation hearing to determine the existence of probable cause for the seizure of his assets. ${ }^{87}$

2. Ordinary Tax Collection. If a prompt postdeprivation probable cause hearing is required for jeopardy collection, surely due process requires at least as much protection of the taxpayer's interest, and maybe more, in ordinary tax collection. A subsequent suit for redress is thus clearly inadequate.

Requiring a predeprivation hearing would give the individual's interest the most protection. Furthermore, the government's interest in the prompt collection of revenue would be frustrated only for the presumably short period of time such a hearing wold require. Since the government lacks an interest in preventing the concealment or transfer of assets, there is no compelling reason to delay

424 U.S. at 633 (citations omitted).

8 If a suit for a Williams Packing injunction is adequate to satisfy the demands of due process in jeopardy tax seizures, no change in existing procedures at the federal or state levels will be required. Aggrieved taxpayers can simply bring suits for injunctions in federal court. 
notice and hearing until after the government controls the assets. ${ }^{88}$ Several recent due process cases offer some support for this position. In Goldberg $v$. Kelly ${ }^{89}$ the Court held that a predeprivation hearing was required, and in Sniadach v. Family Finance Corp..$^{90}$ and Fuentes $v$. Shevin ${ }^{91}$ the Court suggested in dictum that a predeprivation hearing was required.

The broad dicta of these early cases have been limited by more recent cases, however, in which the Court has recognized that due process may often be satisfied by affording the individual less than a predeprivation hearing. ${ }^{92}$ The dicta in the early cases were a reaction to the status quo, which provided only a subsequent suit for redress to the individual whose property was seized. Later cases have concurred in finding a need for greater procedural due process safeguards against the possibility of irreparable harm, but without going so far as to require a predeprivation hearing.

Given the government's interest in speedy collection of its revenues, and the possibility for delay created by predeprivation proceedings-even where the only issue is probable cause-the recent due process cases suggest that a prompt postdeprivation hearing testing probable cause will be adequate. Although this requirement is similar to the procedure required for jeopardy tax seizures, there is one significant difference-the amount of notice required. Notice is not required before a jeopardy tax collection because notice might frustrate the government's interest by enabling the taxpayer to conceal or transfer his assets. In contrast, in ordinary tax collection the taxpayer should be notified of his tax liability before his property can be seized. After notice of his tax liability has been given to the taxpayer, his assets could be seized to collect delinquent taxes, and the taxpayer would still be able to contest the probable cause for this seizure in a prompt postdeprivation hearing.

\section{The Impact on Tax Collection Procedures}

The conclusion that the government must afford the taxpayer, both in jeopardy and ordinary tax collection, an opportunity for at

se See note 59 supra. The magnitude of this governmental interest is suspect. Although tax revenue is essential to the government's operation, its prompt collection may be unnecessary. If the government can operate on a deficit budget, the government's only interest may be in the eventual collection of the tax revenue. Interest can be assessed for the interim period.

397 U.S. 254 (1970).

ง 395 U.S. 337 (1969).

" 407 U.S. 67 (1972).

12 Mitchell v. W.T. Grant, 416 U.S. 600 (1974). 
least a prompt postdeprivation hearing will have only a limited impact on federal tax collection but will greatly affect state tax collection.

1. Federal Tax Collection. In the ordinary collection of federal taxes $^{93}$ the taxpayer is at present afforded an opportunity for a predeprivation hearing or, in other words, as much or more protection than due process requires. Federal taxes are self-assessed..$^{94}$ If the Internal Revenue Service, through either its original inspection or a later audit of the taxpayer's return, concludes that more taxes are owed to the government, the taxpayer has 30 days to meet with revenue agents and discuss the problem. If no meeting is held, or if the two sides cannot reach an agreement, the Service declares the taxpayer to be deficient in his taxes. The taxpayer then has 90 days to file a petition in the Tax Court challenging the deficiency assessment. Petitioning the Tax Court affords the taxpayer an opportunity to be heard, and the taxes will not be collected either until the 90-day filing period has expired or, if a petition is filed, until the Tax Court has decided the case. Only if the taxpayer fails to petition the Tax Court will his property be seized without a hearing, and he can still sue for a refund in a federal district court or the Court of Claims. ${ }^{95}$ Since the federal taxpayer is afforded notice and an opportunity to be heard by a fair and impartial tribunal before the seizure of his property, no procedural due process problem should arise.

In contrast, when summary proceedings have to be used to collect the tax, procedural due process problems can arise. The Court's dictum in Shapiro, however, suggests that an opportunity for at least a prompt postdeprivation probable cause hearing is required for a jeopardy collection. Another summary procedure used by the Internal Revenue Service is the termination of a taxpayer's taxable year, under which the Commissioner, if he finds that the collection of taxes is jeopardized, may declare the taxpayer's taxable year to be at an end. ${ }^{96}$ Until recently this procedure was followed by an immediate seizure of property without notice or a hearing. However, in Laing $v$. United States, ${ }^{97}$ the Supreme Court held that a termination of the taxable year in itself only creates a defi-

${ }^{93}$ Federal estate, excise, and income taxes can be considered together since the collection of all such taxes is governed by the same sections of the Internal Revenue Code. I.R.C. $\$ 6201$.

of Federal taxes payable by stamps are the only major exceptions to the general rule of self-assessment by tax returns for federal taxes.

95 Admin. Conf. Report, supra note 74 , at $282-83$.

${ }^{98} I d$. at $298-99$.

97 423 U.S. 161 (1976). 
ciency, and thus the taxpayer is entitled to the normal collection procedures (including 90 days to petition the Tax Court) which provide an opportunity to be heard before the property is taken. ${ }^{98}$

2. State Tax Collection. The present tax collection procedures of many states do not provide the taxpayer an opportunity for at least a prompt postdeprivation hearing. These procedures afford the taxpayer less protection than due process probably requires..$^{99}$

State courts have approved jeopardy collection procedures that do not provide an opportunity for an early hearing. For example, in Anderson Brothers Co. $v$. Stone $e^{100}$ the Mississippi taxing authorities seized a taxpayer's property because the taxpayer was about to remove the property from the state. The Mississippi Supreme Court held that the seizure did not violate procedural due process so long as the taxpayer had a right to an eventual hearing. ${ }^{101}$ Many states have adopted statutes that similarly allow jeopardy seizures without a prompt postdeprivation hearing. ${ }^{102}$

Similarly, the procedures of many states for ordinary tax collection do not provide for an early hearing. In upholding these procedures against constitutional attack, state and federal courts have relied on language in Supreme Court cases such as Phillips and Nickey. The courts have said that due process is afforded so long as the taxpayer has an eventual opportunity to sue for a refund of the tax. For example, in Bomher v. Reagan ${ }^{103}$ the Ninth Circuit upheld against a constitutional challenge a California statute that allowed seizure and sale of a taxpayer's property for which the only remedy available to the taxpayer was a subsequent suit for redress. Similarly, in Gainesville-Hall County Economic Opportunity Organization v. Blackmon ${ }^{104}$ the Georgia Supreme Court, with sweeping language, upheld a state tax statute that provided an aggrieved taxpayer no remedy other than a subsequent suit for redress. ${ }^{105}$

" The impact of Laing may be quite limited since the Commissioner can escape the logic of the ruling by merely asserting the need for a jeopardy seizure. Since the conditions allowing termination and jeopardy seizures are almost identical, such seizures would generally be proper. For an interesting analysis of Laing, see Roberts, Laing Down a Challenge: The Future of Due Process and Tax Collections, 11 Gonz. L. Rev. 369 (1976).

" For a listing of many statutes that are probably objectionable under this analysis, see note 6 supra.

${ }^{100} 227$ Miss. 26,85 So. $2 d 767$ (1956).

101 Id. at 46,85 So. $2 \mathrm{~d}$ at 775 .

102 See note 6 supra.

sas 522 F.2d 1201 (9th Cir. 1975). See text at notes 52-53 supra.

tat 233 Ga. 507, 212 S.E.2d 341 (1975).

${ }^{105}$ For other cases reaching similar results see Creque v. Shulterbrandt, 121 F. Supp. 448 (D.V.I. 1954); People v. Santa Fe Fed. Sav. \& Loan Ass'n, 28 Cal. 2d 692, 171 P.2d 713 (1946); 
Other states have statutory provisions similar to those approved in Bomher and Gainesuille-Hall. ${ }^{106}$

Under the suggested due process analysis, such procedures would have to be disapproved because they fail to provide an opportunity for at least a prompt postdeprivation hearing to determine the probable validity of the seizure. A state that currently does not afford taxpayers such a prompt postdeprivation hearing in its ordinary tax collection procedures should change its procedures. Several types of ordinary tax collection procedures are possible. The state could adopt tax collection procedures similar to the procedures used by the federal government. ${ }^{107}$ Under the federal procedures for tax collection, the taxpayer is ordinarily afforded an opportunity for a predeprivation hearing. ${ }^{108}$ Only when the collection of tax is thought to be jeopardized is property seized before a hearing, ${ }^{109}$ and then the Shapiro dictum indicates that the taxpayer should be afforded an opportunity for a prompt postdeprivation hearing. The federal tax collection procedures thus distinguish between jeopardy collection, in which seizure of the taxpayer's property before a hearing is justified, and ordinary tax collection, in which the taxpayer's property need not be seized before a hearing is provided because the eventual collection of the tax is not threatened. The federal procedures largely eliminate the possibility of irreparable harm due to a wrongful deprivation while protecting the collection of revenue. However, some states may hesitate to adopt tax collection procedures with the built-in delays of the federal procedures. ${ }^{10}$ This may be particularly disadvantageous as the taxpayer can use the waiting periods to delay the collection of taxes at minimal expense. ${ }^{11}$ Additionally, the federal procedures may impose a larger administrative burden than the states are willing to bear, especially if the state would have to create a permanent tax tribunal.

Frye v. Haas, 182 Neb. 73, 152 N.W.2d 121 (1967) (dictum); New York, Susquehanna \& W.R.R. v. Verneuler, 44 N.J. 491, 210 A.2d 214 (1965).

${ }^{106}$ See note 6 supra.

${ }^{107}$ Some states have adopted procedures similar to the federal procedures. See, e.g., ILL. AnN. Stat. ch. 120, § 9-902 (Smith-Hurd 1970); Mich. Comp. Laws AnN. §§ 211.1-211.157 (1967). See also Comment, The Michigan Property Tax: Assessment, Equalization, and Taxpayer Appeals, 17 WaYNe L. REv. 1397 (1971).

10s I.R.C. \& 6213(a).

${ }^{109}$ I.R.C. $\$ \S 6861-6862$.

110 The federal procedures delay tax collection at least 120 days. See text and notes at notes 93-95 supra.

III Interest could be levied against uncollected tax liabilities, as the federal government has done, I.R.C. $\$ 6601$, but unless the interest charge is punitive, the taxpayer would still have little incentive to avoid the charge. 
If a state is unwilling to imitate the federal procedures, it could adopt procedures that afford the taxpayer simply a prompt postdeprivation hearing. Various procedures would be constitutionally adequate. For instance, the state could adopt tax collection procedures similar to the Louisiana sequestration procedures that the Court approved in Mitchell v. W.T. Grant Co. ${ }^{12}$ The taxpayer would be afforded a judicial hearing immediately after the seizure of his property. Although the burden of proof could rest on the taxpayer to show that the tax was incorrectly assessed or improperly levied, the government would have to set forth the probable correctness or propriety of the tax. The administrative burden imposed by this procedure would be tolerable because the judicial tribunals already exist. The state may, however, be reluctant both to add to the burden on its judicial system and to refer specialized questions of tax law to a nonexpert tribunal. Alternatively, the state could establish an administrative tribunal to afford the necessary opportunity for a prompt postdeprivation hearing. An administrative hearing would not only be constitutionally adequate, ${ }^{113}$ but would allow the referral of tax questions to an expert tribunal. If the state already has an administrative tribunal for tax matters, the state need only add to its jurisdiction. If the state must establish such a tribunal, the establishment may impose a greater burden on the state. Presumably the burden imposed will be less if the taxpayer is offered a prompt postdeprivation hearing than if he is offered a predeprivation hearing because taxpayers who want simply to stall the collection of taxes will not petition to be heard.

\section{CONCLUSION}

Although courts have often upheld tax collection procedures that afford the taxpayer deprived of his property only an opportunity for a subsequent suit for redress, this result is at odds with the more recent due process cases, which have required that a person deprived of his property must be afforded an opportunity for a predeprivation or prompt postdeprivation hearing. Courts upholding tax collection procedures have relied on language in early Supreme

112416 U.S. 600 (1974). The Louisiana sequestration statute in Mitchell provided for preseizure judicial approval of the deprivation of property which meant that a judge had to sign the order of sequestration. To obtain this approval, the creditor had to file affidavits supporting his claim. 416 U.S. at 626 . Although it could be argued that this procedure adequately protected the debtor because it required a judicial finding of probable cause, this ex parte determination is not the same as an opportunity to be heard, which the taxpayer in Mitchell was afforded immediately after the seizure.

113 Goldberg v. Kelly, 397 U.S. 254, 271 (1970). 
Court cases, but close examination shows that in those cases the taxpayer was actually afforded an opportunity for a predeprivation hearing. In dictum in Commissioner v. Shapiro the Supreme Court attempted to bring tax collection procedures into line with the requirements developed in other due process cases. The Court said that the taxpayer in a jeopardy collection situation must be afforded an opportunity for at least a prompt hearing to test the probable validity of the seizure, and its conclusion implies that the taxpayer in an ordinary tax collection situation must be afforded at least as much protection. An analysis of the competing interests confirms this result because a prompt postdeprivation hearing protects the taxpayer against possible harm due to a wrongful deprivation and at the same time provides for the prompt collection of taxes. Although the Court in Shapiro indicated that the individual would be required to prove irreparable harm in this hearing, this requirement is at odds with the decisions on which the dictum was based and is not supported by any legitimate governmental interest. The tax collection procedures of many states should be amended to afford the taxpayer an opportunity for such a hearing.

Richard M. Lipton 